\title{
Sequence variation and mRNA expression of the TWIST1 gene in cats with mammary hyperplasia and neoplasia
}

\author{
Cláudia S. Baptista ${ }^{\mathrm{a}, \mathrm{b}, 1}$, Sara Santos ${ }^{\mathrm{b}, 1}$, António Laso ${ }^{\mathrm{c}}$, Estela Bastos ${ }^{\mathrm{b}, \mathrm{d}}$, Sílvia Ávila ${ }^{\mathrm{c}}$, \\ Henrique Guedes-Pinto ${ }^{\mathrm{b}}$, Fátima Gärtner ${ }^{\mathrm{e}, \mathrm{f}}$, Ivo G. Gut ${ }^{\mathrm{g}}$, José L. Castrillo ${ }^{\mathrm{c}}$, Raquel Chaves ${ }^{\mathrm{b}, \mathrm{d}, \Uparrow}$ \\ ${ }^{\text {a }}$ Department of Veterinary Clinics, Institute of Biomedical Sciences Abel Salazar, University of Porto (ICBAS - UP), Largo Prof. Abel Salazar, 2, 4099-003 Porto, Portugal \\ ${ }^{b}$ Institute for Biotechnology and Bioengineering, Centre of Genomics and Biotechnology, University of Trás-os-Montes and Alto Douro (IBB/CGB-UTAD), Quinta de Prados, \\ 5001-801 Vila Real, Portugal \\ ${ }^{c}$ Genetadi Biotech, Parque Tecnológicode Bizkaia, Edificio 502, 48160 Derio, Spain

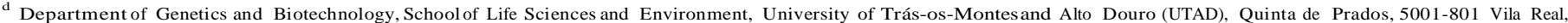 \\ Portugal \\ e Institute of Pathology and Immunology(IPATIMUP), University of Porto, Rua Dr. Roberto Frias, s/n, 4200-465 Porto, Portugal \\ ${ }^{\mathrm{f}}$ Department of Pathology and Molecular Immunology,Institute of Biomedical Sciences Abel Salazar, University of Porto (ICBAS - UP), Largo Prof. Abel Salazar, 2, 4099-003 \\ Porto, Portugal \\ ${ }^{g}$ CEA/DSV/IG-Centre National de Génotypage, Bâtiment G2, 2 rue Gaston Crémieux, CP 5721, 91057 Evry Cedex, France
}

\section{a $\mathrm{r}$ t i c l e i n f o}

Keywords:

Feline

TWIST1 gene

Mammary gland

Hyperplasia

Neoplasia

Sequence variation

mRNA expression

\section{a b s t r a c t}

In humans, a germline mutation $(\mathrm{c} .309 \mathrm{C}>\mathrm{G})$ in the TWIST1 oncogene may predispose to breast cancer and its expression has been associated with tumour progression and metastasis. In this study, the feline TWIST1 gene was screened for sequence variations in 37 neoplastic and eight hyperplastic mammary gland lesions from cats. In addition, mRNA levels were examined in 15 mammary tumours and three cases of mammary hyperplasia by quantitative real-time reverse-transcriptase PCR. Feline mammary car- cinomas had significantly lower levels of expression of TWIST1 mRNA than benign mammary tumours. No variations were identified in the TWIST1 coding region in feline mammary tumours and the mutation described in humans was not detected. However, two germline variants in the TWIST1 gene intron were identified in four and three carcinomas, respectively: GQ167299:g.535delG and GQ167299:g.460C>T. There was no association between these sequence alterations and TWIST1 mRNA levels.

2011 Elsevier Ltd. All rights reserved.
Introduction

Mammary tumours account for $17 \%$ of tumours in female cats and usually exhibit more aggressive biological behaviour than mammary tumours in humans or dogs, with $85-93 \%$ of tumours being malignant (Schmidt and Langham, 1967; Hayes et al.,

1981; Bostock, 1986). Due to similarities in pattern of metastasis, molecular characteristics and histopathological appearance, feline mammary carcinoma has been proposed as a comparative model to study hormone-independent human breast carcinomas (Zappul- li et al., 2005).

TWIST1 is an oncogene encoding the Twist-1 protein, a basic helix-loop-helix DNA-binding transcription factor (Yang et al., 2004). This protein regulates embryonic morphogenesis, enhances cell survival in response to cytotoxic stress and promotes invasive behaviour during tumour progression (Yang et al., 2004; Foubert

\footnotetext{
$\Uparrow$ Corresponding author. Tel.: +351259350841 E-mail address: rchaves@utad.pt (R. Chaves). Both authors contributed equally to this work.
}

et al., 2010). TWIST1 may also contribute to acquired paclitaxel and vincristine resistance (Wang et al., 2004; Cheng et al., 2007).

Several mutations in the coding sequence of the human TWIST1 gene, leading to haploinsufficiency, have been identified in Saethre-Chotzen syndrome (SCS) (Yousfi et al., 2002), human paediatric osteosarcomas (Entz-Werle et al., 2005) and some cases of Baller-Gerold syndrome (Gripp et al., 1999). Sahlin et al. (2007) reported that women with SCS had an increased risk of breast cancer, although this association was not confirmed in another study (James et al., 2009). A germline TWIST1 mutation c.309C $>\mathrm{G}$ has been identified as a disease-specific mutation in patients with SCS (El Ghouzzi et al., 1997; Paznekas et al., 1998). This single nucleotide change generates a stop codon at amino acid residue 103, resulting in premature termination of the Twist-1 protein and loss of function (Paznekas et al., 1998).

Gort et al. (2008) found no clear differences in TWIST1 mRNA levels between normal and malignant breast tissue in humans. Other studies have suggested that increased TWIST1 mRNA expres- sion may play a role in mammary carcinogenesis (Watanabe et al., 2004; Yang et al., 2004), including an association with decreased survival time (Martin et al., 2005) and early systemic tumour relapse (Watson et al., 2007; Tjensvoll et al., 
2010). Low expression of Twist-1 protein and TWIST1 mRNA in triple negative (oestrogen receptor, progesterone receptor and HER-2 negative) invasive duc- tal carcinomas of the breast have been correlated with poor overall survival (Montserratet al., 2011).

Previously, we sequenced part of the TWIST1 gene in the cat (GenBank GQ167299) and demonstrated a high similarity with the corresponding human sequence (Baptista et al., 2010). In the present study, we screened 45 feline mammary gland lesions, including hyperplasia and benign and malignant neoplasia, for sequence variations in the TWIST1 gene, in particular looking for the c.309C $>\mathrm{G}$ mutation described in human breast cancer (Sahlin et al., 2007). Additionally, we examined the expression pattern of TWIST1 mRNA in 15 mammary gland tumours and three cases of mammary gland hyperplasia by quantitative real-time reverse-transcriptase PCR (qRT-PCR).

Materials and methods

Source of samples

Direct PCR sequencing of the TWIST1 gene was performed on DNA extracted from eight hyperplastic mammary lesions, three benign mammary neoplasms and 34 malignant mammary tumours from 45 queens (median age 9.5 years, range 3-15 years). Of these 45 mammary masses, 11 were fresh tissues collected during surgery and the remaining 34 samples were formalin-fixed and paraffin-embedded (FFPE) tissues from diagnostic biopsies. A control group consisted of DNA extracted from four normal mammary glands and three blood samples obtained from seven queens $>5$ years of age with no evidence of clinical disease. The blood samples were collected by venipuncture into heparin-treated tubes after the owners' consent. Four unaffected skin samples, biopsied during surgery, were collected from animals also bearing a mammary gland carcinoma. Mammary lesions were characterised histologically according to Misdorp et al. (1999).

To measure TWIST1 specific transcripts by qRT-PCR, 25 normal, hyperplastic and neoplastic feline mammary gland tissues were collected and stored at $80 \mathrm{C}$ in RNALater(Ambion). Hyperplastic $(\mathrm{n}=3)$ and neoplastic $(\mathrm{n}=15)$ mammary gland le- sions were collected at routine surgery from 15 queens (3 speyed, 12 intact) with a mean age of 10.5 years (range 4-20 years). One of these queens was initially diag- nosed with fibroadenomatous change (sample 1) and subsequently developed two carcinomas (samples 15 and 16). Normal mammary gland samples (n = 7) were col- lected postmortem from seven different queens ( 3 speyed, 4 intact) $>5$ years of age with no evidence of clinical disease that were humanely euthanased as part of the national stray cat control programme. All samples were collected in accordance with EU Directive 2010/63/EU (Ethic Commission of Porto University approval number EC/1204/POCI/CVT/62940/2004).

\section{Extraction of DNA}

DNA was extracted from fresh mammary tissue samples using the Quick-Gene DNA Tissue Kit S (Fujifilm Life Science) and from FFPE tissues as described by Santos et al. (2009). DNA was also extracted from $2001 \mathrm{~L}$ total blood using the Quickgene-810 (Fujifilm) and the QuickGene Whole Blood Kit S (Fujifilm). To analyse the integ- rity of the genomic DNA, all samples were analysed by $1.5 \%$ agarose gel electropho- resis. The quantity and quality of DNA was also determined using the NanoDrop ND-1000 spectrophotometer.

Extraction and purification of RNA

Total RNA was extracted from all tissue samples with Trizol (Invitrogen Life Technologies) and total RNA purification was performed with the RNAeasy Mini Kit (Qiagen). RNA integrity was assessed using the 2100 Bioanalyzer (Agilent Tech- nologies) and only samples with an RNA integrity number (RIN) $>7.5$ were used. The total RNA concentration was measured using the NanoDrop ND-1000 spectrophotometer.

\section{PCR for amplification and sequencing of TWIST1 gene sequences}

Fragments of 201,316 and 1011 base pairs (bp) were amplified using DNA from fresh tissues (11/45), whereas only fragments of 201 and 316 bp (covering the par- tial coding region) were amplified from FFPE tissues due to the likelihood of DNA degradation. The PCR steps, reaction mixture, primer sequences and combinations have been published by Baptistaet al. (2010) for the $316 \mathrm{bp}$ and 1011 bp fragments.

For amplification of the $201 \mathrm{bp}$ fragment, a $251 \mathrm{~L}$ volume contained a final concentration of $8 \mathrm{ng}$ genomic DNA, $4 \mathrm{ng}$ each oligonucleotide primer (F: $5^{0}$ GAG- CCCGCAGTCGTACGAG- $3^{0}$ and R: $5^{10}$-CTCTGGAGGACCTGGTAGAGGA- $3^{0}$ ), $0.15 \mathrm{mM}$ each deoxynucleotide triphosphate, $1.5 \mathrm{mM} \mathrm{MgCl}_{2}, 1 \mathrm{Taq}$ buffer and $0.1 \mathrm{U}$ Taq DNA polymerase (Fermentas). PCR steps consisted of initial denaturation at $95 \mathrm{C}$ for $5 \mathrm{~min}, 29$ cycles of denaturation at $95 \mathrm{C}$ for $30 \mathrm{~s}$, annealing at $55 \mathrm{C}$ for $30 \mathrm{~s}$ and extension at $72 \mathrm{C}$ for $30 \mathrm{~s}$, with final extension at $72 \mathrm{C}$ for $5 \mathrm{~min}$, followed by cooling to $4 \mathrm{C}$. Each PCR product was separated on a $1 \%$ agarose gel and analysed and recorded under ultraviolet light.

PCR products were purified and the sequencing cycle reactions were performed in both directions using the DNA Sequencing Kit (ABI Prism). The sequencing reaction mixtures were analysed on an Applied Biosystems 3730xl capillary electrophoresis-based genetic analyser at the Centre National de Génotypage, France Sequences were analysed using Vector NTI software (Invitrogen Life Technologies). All sequence alterations are described as recommended by the Human Genome Variation Society (HGVS) (Oginoet al., 2007).

\section{Quantitative real-time RT-PCR to measure TWIST1 gene mRNA expression}

Primers (F: $5^{0}$-GGCTCAGCTACGCCTTCTC- $3^{n}$ and R: $5^{0}$-CTAGTGGGACGCGGACAT$3^{\|}$) were designed with the RocheLightCycler Probe Design Software 2.0. A hybridisation probe was selected from the Universal Probe Library from Roche Applied Science (UPL58). For qRT-PCR analysis, $350 \mathrm{ng}$ total RNA from each tissue sample in a reaction volume of $201 \mathrm{~L}$ were reverse transcribed into cDNA using the Roche Transcriptor Hi-Fi cDNA synthesis kit (Roche Applied Science). PCR amplification was performed using the LightCycler 480 Probes Master (Roche Applied Science) with a total reaction volume of $201 \mathrm{~L}$ containing $51 \mathrm{~L}$ cDNA $(1 / 10$ diluted in nucle- ase free water), $4.4 \mathrm{1L}$ water, $201 \mathrm{M}$ probe, $201 \mathrm{M}$ forward primer, $201 \mathrm{M}$ reverse primer and $101 \mathrm{~L}$ LCMaster.

Each gene expression assay was performed in triplicate using the LightCycler 480 Real-Time PCR System (Roche Applied Science). Amplification was carried out as follows: pre-incubation at $95 \mathrm{C}$ for $10 \mathrm{~min}, 50$ cycles of denaturation at $95 \mathrm{C}$ for $10 \mathrm{~s}$, annealing at $60 \mathrm{C}$ for $30 \mathrm{~s}$, elongation at $72 \mathrm{C}$ for $1 \mathrm{~s}$ and fluores- cence acquisition $(483-533 \mathrm{~nm})$, then a final cooling at $40 \mathrm{C}$ for 10 s. Each PCR con-tained a non-template control and a calibrator reference consisting of a normal mammary gland sample. The GAPDH gene was used as a housekeeping gene for nor- malisation of assays.

\section{Statistical analysis}

Statistical analyses were performed using Microsoft Excel 2007. All reported $P$ values (Student's $t$ test) are two-sided and statistical significance was defined as $\mathrm{P}<0.05$.

Results

\section{TWIST1 gene sequence analysis}

Partial TWIST1 gene sequences were analysed in tissue from eight hyperplastic mammary lesions and 37 mammary neoplasms ( 3 benign and 34 malignant) from 45 queens. Five of eight cases of mammary gland hyperplasia presented with multiple lesions and all were diagnosed as fibroadenomatous change. All three benign tumours were classified as low cellularity fibroadenomas, two of which presented with multiple masses. Categories of malignant tu- mours are shown in Table 1. Using three primer combinations, PCR products were amplified from 11 fresh frozen lesions and 11 fresh frozen control tissues, as well as products from 34 FFPE lesions. We sequenced 697 and 960 bp in both directions from 5 and 6 fresh frozen lesions, respec- tively $(\mathrm{n}=11 / 45)$ and 266 and $316 \mathrm{bp}$ in both directions from 10 and 24 FFPE lesions, respectively ( $\mathrm{n}=$ 34/45). We also sequenced $960 \mathrm{bp}$ in both directions from 11 fresh frozen control samples (se- ven samples from disease-free animals and four samples from unaffected tissue of queens 
with mammary gland carcinomas).

All sequences of the TWIST1 gene amplified from the abnormal mammary gland tissues were compared with the control TWIST1 gene sequences. No nucleotide alterations were detected in the partial coding region of 45 mammary masses from frozen or FFPE tissues in which either 316 bp (30/45) or $266 \mathrm{bp}(15 / 45)$ were se- quenced, as inferred from the orthologous gene in humans (Sup- plementary Fig. 1). In 4/6 frozen mammary carcinomas in which 960 bp were sequenced, we detected a $\mathrm{G}$ deletion in the predicted intronic region (GQ167299:g.535delG); the same deletion was also detected in corresponding normal control tissue from the same animals. Three of these tumours, as well the matching controls, also presented a heterozygous transition (GQ167299:g.460C $>$ T) in the intron (Table 1).

\section{TWIST1 gene mRNA expression}

TWIST1 mRNA expression was evaluated in 25 frozen feline mammary gland tissues: seven normal glands, three hyperplastic lesions, one benign tumour and 14 carcinomas. Carcinomas had significantly lower TWIST1 mRNA levels than benign lesions $(\mathrm{P}<0.015)$ and disease-free mammary glands ( $\mathrm{P}<0.0007)$ (Ta- ble 2$)$. One tubular carcinoma with a $G$ deletion in the predicted intronic region (GQ167299:g.535delG) had low TWIST1 mRNA expression. Two carcinomas (tubulopapillary/solid and tubular) without any sequence variation in the TWIST1 gene also had low TWIST1 mRNA levels relative to other carcinomas. Cases of fibroadenomatous change and the low-cellularity fibroadenoma had low mRNA levels and did not have any sequence alterations. There was no association between the feline TWIST1 sequence variants identified in this study and TWIST1 mRNA levels.

\section{Discussion}

In humans, it has been shown that dominant predisposition alleles, mutations and single nucleotide polymorphisms (SNPs), additively or synergistically, contribute to increased breast cancer risk (Wooster et al., 1995; Goode et al., 2002; Mitrunen and Hirvo-nen, 2003; Onay et al., 2006). An increased risk of breast cancer in women with SCS, an autosomal, dominantly inherited craniosynostosis caused by mutations in the TWIST1 gene, has been identified, suggesting that germline mutations in TWIST1 may predispose to breast cancer (Sahlin et al., 2007).

In the present study, 45 feline mammary tissue samples were evaluated for the presence of the mutation described by Sahlin et al. (2007), but this nucleotide alteration, as well as other sequence variations, was not detected in the partial coding region (316 bp in 30/45 masses and 266 bp in $15 / 45$ samples) of any of the feline mammary lesions analysed. However, it remains to be determined whether any sequence variants are present in segments of the feline TWIST1 gene that have not been analysed. Furthermore, we could not obtain sequences from all samples, possibly due to partial nucleic acid degradation during formalin fixation and storage.

Both exons and introns should be investigated to recognise potentially important nucleotide sequence alterations that may have an effect on alternative splicing (Di Leo et al., 2007). In this study, we screened segments of the intronic region of the TWIST1 gene in 11 feline mammary masses. We identified two sequence variations (GQ167299:g.535delG and GQ167299:g.460C $>$ T) in the intronic region of the TWIST1 gene in four malignant mammary tumours. Intron retention splicing of the TWIST1 gene has not been reported in humans, so it is uncertain whether this mechanism oc- curs in this gene in cats. SNPs altering conserved amino acids are more likely to be associated with cancer susceptibility (Zhu et al., 2004) and thus it is improbable that sequence variations localised in the nonconserved intronic regions are associated with neoplasia. To confirm the significance of the nucleotide alterations reported here, we compared sequences from hyperplastic and neoplastic lesions with unaffected tissue biopsied from the same cats. Similar sequence variations were observed in all samples, indicating that these nucleotide alterations represent germline variants of the feline TWIST1 gene.

In this study, feline carcinomas had significantly lower TWIST1 mRNA levels than benign lesions and disease-free mammary glands. In breast cancer, altered (increased or decreased) TWIST1 mRNA expression has been associated with poor prognosis, shorter patient survival and appearance of metastases (Montserrat et al., 2011; Tjensvoll et al., 2010). Expression of TWIST1 may contribute to tumour metastasis by promoting an epithelial to mesenchymal transition (EMT) (Yang et al., 2004). Down-regulation of TWIST1 may be determined by an epigenetic mechanism (Gort et al., 2008), as has been identified during induction of EMT in basal-like breast cancer cell lines (Dumont et al., 2008).

\section{Conclusions}

Two germline sequence variants (GQ167299:g.535delG and GQ167299:g.460C > T) were identified in intronic regions of the fe- line TWIST1 gene. There was no association between the presence of these variants and the occurrence of hyperplastic lesions or benign or malignant neoplasms in the feline mammary gland. Expression of feline TWIST1 mRNA was lower in feline carcinomas than in benign mammary tumours.

\section{Conflict of interest statement}

None of the authors of this paper has a financial or personal relationship with other people or organisations that could inappropriately influence or bias the content of the paper.

Acknowledgements

This work was supported by the Project
Gr/CVT/62940/2004 and the POCI/CVT/62940/2004 and the PhD Grants
SFRH/BD/31754/2006 and SFRH/BD/234/2005 of the Science and Technology Foundation (FCT) from Portugal.

Appendix A. Supplementary material

Supplementary data associated with this article can be found, in the online version, at doi:10.1016/j.tvj1.2011.01.011. 


\section{References}

Baptista, C.S., Bastos, E., Santos, S., Gut, I.G., Guedes-Pinto, H., Gärtner, F., Chaves, R., 2010. TWIST1 gene: First insights in Felis catus. Current Genomics 11, 212-220. Bostock, D.E., 1986. Canine and feline mammary neoplasms. British Veterinary Journal 142, 506-515.

Cheng, G.Z., Chan, J., Wang, Q., Zhang, W., Sun, C.D., Wang, L.H., 2007. Twist transcriptionally up-regulates AKT2 in breast cancer cells leading to increased migration, invasion, and resistance to paclitaxel. Cancer Research 67, 1979-1987.

Di Leo, E., Magnolo, L., Lancellotti, S., Crocè, L., Visintin, L., Tiribelli, C., Bertolini, S., Calandra, S., Tarugi, P., 2007. Abnormal apolipoprotein B pre-mRNA splicing in patients with familial hypobetalipoproteinaemia. Journal of Medical Genetics 44, 219-224.

Dumont, N., Wilson, M.B., Crawford, Y.G., Reynolds, P.A., Sigaroudinia, M., Tlsty, T.D., 2008. Sustained induction of epithelial to mesenchymal transition activates DNA methylation of genes silenced in basal-like breast cancers. Proceedings of the National Academy of Sciences USA 105, 14867-14872.

El Ghouzzi, V., Le Merrer, M., Perrin-Schmitt, F., Lajeunie, E., Benit, P., Renier, D., Bourgeois, P., Bolcato-Bellemin, A.L., Munnich, A., Bonaventure, J., 1997. Mutations of the TWIST gene in the SaethreChotzen syndrome. Nature Genetics 15, 42-46.

Entz-Werle, N., Stoetzel, C., Berard-Marec, P., Kalifa, C., Brugiere, L., Pacquement, H., Schmitt, C., Tabone, M.D., Gentet, J.C., Quillet, R., Oudet, P., Lutz, P., Babin- Boilletot, A., Gaub, M.P., Perrin-Schmitt, F., 2005. Frequent genomic abnormalities at TWIST in human pediatric osteosarcomas. International Journal of Cancer 117, 349-355.

Foubert, E., De Craene, B., Berx, G., 2010. Key signalling nodes in mammary gland development and cancer. The Snail1-Twist1 conspiracy in malignant breast cancer progression. Breast Cancer Research 12, 206.

Goode, E.L., Ulrich, C.M., Potter, J.D., 2002. Polymorphisms in DNA repair genes and associations with cancer risk. Cancer Epidemiology, Biomarkers and Prevention 11, 1513-1530.

Gort, E.H., Suijkerbuijk, K.P., Roothaan, S.M., Raman, V., Vooijs, M., van der Wall, E., van Diest, P.J., 2008. Methylation of the TWIST1 promoter, TWIST mRNA levels, and immunohistochemical expression of TWIST1 in breast cancer. CancerEpidemiology, Biomarkers and Prevention 17, 3325-3330.

Gripp, K.W., Stolle, C.A., Celle, L., McDonald-McGinn, D.M., Whitaker, L.A., Zackai, E.H., 1999. TWIST gene mutation in a patient with radial aplasia and craniosynostosis: further evidence for heterogeneity of Baller-Gerold syndrome. American Journal of Medical Genetics 82, 170-176.

Hayes Jr, H.M., Milne, K.L., Mandell, C.P., 1981. Epidemiological features of feline mammary carcinomas. Veterinary Record 108, 476-479.

James, P.A., Culling, B., Mullan, G., Jenkins, M., Elakis, G., Turner, A.M., Mowat, D.M., Wilson, M., Anderson, P., Savarirayan, R., Cliffe, S.T., Caramins, M., Buckley, M.F., Tucker, K., Roscioli, T., 2009. Breast cancer risk is not increased in individuals with TWIST1 mutation confirmed SaethreChotzen syndrome: an Australian multicenter study. Genes, Chromosomes and Cancer 48, 533-538.

Martin, T.A., Goyal, A., Watkins, G., Jiang, W.G., 2005. Expression of the transcription factors Snail, Slug, and Twist and their clinical significance in human breast cancer. Annals of Surgical Oncology 12, 488-496.

Misdorp, W., Else, R., Hellmen, E., Lipscomb, T., 1999. Histological Classification of Mammary Tumours of the Dog and the Cat, second ed. Armed Forces Institute of Pathology, Washington, USA.

Mitrunen, K., Hirvonen, A., 2003. Molecular epidemiology of sporadic breast cancer. The role of polymorphic genes involved in oestrogen biosynthesis and metabolism. Mutation Research 544, 9-41.

Montserrat, N., Gallardo, A., Escuin, D., Catasus, L., Prat, J., GutiérrezAvignó, F.J., Peiró, G., Barnadas, A., Lerma, E., 2011. Repression of E-cadherin by SNAIL, ZEB1, and TWIST in invasive ductal carcinomas of the breast: a cooperative effort? Human Pathology 42, 103-110.

Ogino, S., Gulley, M.L., den Dunnen, J.T., Wilson, R.B., Association for
Molecular Pathology Training, Education Committee, 2007. Standard mutation nomenclature in molecular diagnostics: practical and educational challenges. Journal of Molecular Diagnostics 9, 1-6 (Erratum: Journal of Molecular Diagnostics 2009; 11, 494).

Onay, V.U., Briollais, L., Knight, J.A., Shi, E., Wang, Y., Wells, S., Li, H., Rajendram, I., Andrulis, I.L., Ozcelik, H., 2006. SNP-SNP interactions in breast cancer susceptibility. BMC Cancer 6, 114

Paznekas, W.A., Cunningham, M.L., Howard, T.D., Korf, B.R., Lipson, M.H., Grix, A.W., Feingold, M., Goldberg, R., Borochowitz, Z., Aleck, K., Mulliken, J., Yin, M., Jabs,

E.W., 1998. Genetic heterogeneity of Saethre-Chotzen syndrome, due to TWIST and FGFR mutations. American Journal of Human Genetics 62, $1370-1380$

Sahlin, P., Windh, P., Lauritzen, C., Emanuelsson, M., Grönberg, H., Stenman, G., 2007. Women with Saethre-Chotzen syndrome are at increased risk of breast cancer. Genes, Chromosomes and Cancer 46, 656660 .

Santos, S., Sá, D., Bastos, E., Guedes-Pinto, H., Gut, I., Gärtner, F., Chaves, R., 2009. An efficient protocol for genomic DNA extraction from formalin-fixed paraffin- embedded tissues. Research in Veterinary Science 86, 421-426.

Schmidt, R.E., Langham, R.F., 1967. A survey of feline neoplasms. Journal of the American Veterinary Medical Association 151, 1325-1328.

Tjensvoll, K., Oltedal, S., Farmen, R.K., Shammas, F.V., Heikkila, R., Kvaloy, J.T., Gilje, B., Smaaland, R., Nordgard, O., 2010. Disseminated tumor cells in bone marrow assessed by TWIST1, cytokeratin 19, and mammaglobin A mRNA predict clinical outcome in operable breast cancer patients. Clinical Breast Cancer 10, 378-384

Wang, X., Ling, M.T., Guan, X.Y., Tsao, S.W., Cheung, H.W., Lee, D.T., Wong, Y.C., 2004. Identification of a novel function of TWIST, a bHLH protein, in the development of acquired Taxolresistance in human cancer cells. Oncogene $23,474-482$.

Watanabe, O., Imamura, H., Shimizu, T., Kinoshita, J., Okabe, T. Hirano, A., Yoshimatsu, K., Konno, S., Aiba, M., Ogawa, K., 2004. Expression of twist and wnt in human breast cancer. Anticancer Research 24, 3851-3856.

Watson, M.A., Ylagan, L.R., Trinkaus, K.M., Gillanders, W.E., Naughton, M.J., Weilbaecher, K.N., Fleming, T.P., Aft, R.L., 2007. Isolation and molecular profiling of bone marrow micrometastases identifies TWIST1 as a marker of early tumor relapse in breast cancer patients. Clinical Cancer Research 13,5001-5009.

Wooster, R., Bignell, G., Lancaster, J., Swift, S., Seal, S., Mangion, J., Collins, N., Gregory, S., Gumbs, C., Micklem, G., 1995. Identification of the breast cancersusceptibility gene BRCA2. Nature 378, 789-792.

Yang, J., Mani, S.A., Donaher, J.L., Ramaswamy, S., Itzykson, R.A., Come, C., Savagner, P., Gitelman, I., Richardson, A., Weinberg, R.A., 2004. Twist, a master regulator of morphogenesis, plays an essential role in tumor metastasis. Cell $117,927-939$.

Yousfi,M., Lasmoles, F., Ghouzzi, V.E., Marie, P.J., 2002. Twist haploinsufficiency in Saethre-Chotzen syndrome induces calvarial osteoblast apoptosis due to increased TNFa expression and caspase-2 activation. Human Molecular Genetics 1, 359-369.

Zappulli, V., De Zan, G., Cardazzo, B., Bargelloni, L., Castagnaro, M., 2005. Feline mammary tumours in comparative oncology. Journal of Dairy Research 72, 98-106

Zhu, Y., Spitz, M.R., Amos, C.I., Lin, J., Schabath, M.B., Wu, X., 2004. An evolutionary perspective on single-nucleotide polymorphism screening in molecular cancer epidemiology. Cancer Research 64, 2251-2257 
Table 1 Clinicopathological features and sequence variations in 45 feline mammary masses.

\begin{tabular}{|c|c|c|c|c|}
\hline Breed & Number of lesions & Histologicalclassification (WHO criteria) & Lymphnode metastasis & Sequence variation $^{\mathrm{a}}$ \\
\hline Domestic shorthaired & Single & Fibroadenomatous change & NA & Absent (960 bp) \\
\hline Siamese & Single & Fibroadenomatous change & NA & Absent (266 bp) \\
\hline Domestic shorthaired & Multiple & Fibroadenomatous change & NA & Absent (316 bp) \\
\hline Domestic shorthaired & Multiple & Fibroadenomatous change & NA & Absent (316 bp) \\
\hline Domestic shorthaired & Multiple & Fibroadenomatous change & NA & Absent (266 bp) \\
\hline Domestic shorthaired & Multiple & Fibroadenomatous change & NA & Absent (266 bp) \\
\hline Domestic shorthaired & Multiple & Fibroadenomatous change & NA & Absent (266 bp) \\
\hline Domestic shorthaired & & Fibroadenomatous change & NA & Absent (266 bp $+431 b p)$ \\
\hline Domestic shorthaired & Multiple & Low-cellularity Fibroadenoma & & Absent (316 bp) \\
\hline Domestic shorthaired & Multiple & Low-cellularity Fibroadenoma & $\mathrm{NE}$ & Absent (266 bp $+431 b p)$ \\
\hline Domestic shorthaired & Single & Low-cellularity Fibroadenoma & $\mathrm{NE}$ & Absent (266 bp) \\
\hline Domestic shorthaired & Multiple & Carcinoma & + & g.535delG (960 bp) \\
\hline Domestic shorthaired & Multiple & Carcinoma & + & g. $460 \mathrm{C}>\mathrm{T} ;$ g. $535 \mathrm{delG}(960 \mathrm{bp})$ \\
\hline Domestic shorthaired & Multiple & Carcinoma & + & g. $460 \mathrm{C}>\mathrm{T} ; \mathrm{g} .535 \mathrm{delG}(960 \mathrm{bp})$ \\
\hline Domestic shorthaired & & Carcinoma & + & Absent $(266 b p+431 b p)$ \\
\hline Domestic shorthaired & Multiple & Carcinoma & $\mathrm{NE}$ & Absent (266 bp + 431 bp) \\
\hline Siamese & Single & Cribriform carcinoma & + & Absent (316 bp) \\
\hline Domestic shorthaired & Multiple & Cribriform carcinoma & $\mathrm{NE}$ & Absent (316 bp) \\
\hline Turkish Angora & Single & Cribriform/solid carcinoma & NE & Absent (316 bp) \\
\hline Domestic shorthaired & Single & Cribriform/solid carcinoma & + & Absent (316 bp) \\
\hline Domestic shorthaired & Multiple & Solid carcinoma & & Absent (316 bp) \\
\hline Domestic shorthaired & Single & Solid carcinoma & & Absent (266 bp) \\
\hline Domestic shorthaired & Multiple & Solid carcinoma & + & Absent (316 bp) \\
\hline Persian & Multiple & Solid carcinoma & + & Absent (316 bp) \\
\hline Domestic shorthaired & Single & Solid carcinoma & + & Absent (316 bp) \\
\hline Domestic shorthaired & Multiple & Solid carcinoma & NE & Absent (316 bp) \\
\hline Domestic shorthaired & Single & Solid carcinoma & NE & Absent (316 bp) \\
\hline Siamese & Multiple & Solid carcinoma & $\mathrm{NE}$ & Absent (266 bp) \\
\hline Domestic shorthaired & Single & Solid carcinoma & + & Absent (266 bp) \\
\hline Domestic shorthaired & Multiple & Solid carcinoma & & Absent (266 bp) \\
\hline Domestic shorthaired & Multiple & Tubular/solid carcinoma & + & Absent (316 bp) \\
\hline Domestic shorthaired & Single & Tubular/solid carcinoma & + & Absent (316 bp) \\
\hline Domestic shorthaired & Multiple & Tubular carcinoma & NE & Absent (266 bp) \\
\hline Domestic shorthaired & Multiple & Tubular carcinoma & & Absent (266 bp $+431 b p)$ \\
\hline Domestic shorthaired & Single & Papillary carcinoma & $\mathrm{NE}$ & Absent (316 bp) \\
\hline Domestic shorthaired & Single & Complex carcinoma & NA & Absent (316 bp) \\
\hline Siamese & Multiple & Tubulopapillary/solid carcinoma & + & Absent (316 bp) \\
\hline Domestic shorthaired & Multiple & Tubulopapillary/solid carcinoma & & Absent (316 bp) \\
\hline Siamese & Single & Tubulopapillary/solid carcinoma & + & Absent (960 bp) \\
\hline Domestic shorthaired & Multiple & Tubulopapillary carcinoma & & g. $460 \mathrm{C}>\mathrm{T} ;$ g. $535 \mathrm{delG}(960 \mathrm{bp})$ \\
\hline Domestic shorthaired & Single & Tubulopapillary carcinoma & $\mathrm{NE}$ & Absent (316 bp) \\
\hline Domestic shorthaired & Multiple & Tubulopapillary carcinoma & $\mathrm{NE}$ & Absent (316 bp) \\
\hline Domestic shorthaired & Multiple & Tubulopapillary carcinoma & $\mathrm{NE}$ & Absent (316 bp) \\
\hline Siamese & Single & Tubulopapillary carcinoma & & Absent (316 bp) \\
\hline Domestic shorthaired & Multiple & Tubulopapillary carcinoma & $\mathrm{NE}$ & Absent (316 bp) \\
\hline
\end{tabular}

, Unknown; +, present; , absent; NE, not evaluated; NA, not applicable; bp, base pair.

a The length (bp) refers the number of nucleotides sequenced and analysed in each sample. Nucleotide numbers refer to the DNA sequence available in GenBank (GQ167299). The nomenclature for sequence alterations is according to the recommendations from the Human Genome Variations Society(Oginoet al., 2007). 
Table 2

Clinicopathological features and TWIST1 mRNA expressionstatus in 18 feline mammary masses.

\begin{tabular}{|c|c|c|c|c|c|c|}
\hline Sample & $\begin{array}{l}\text { Number of } \\
\text { lesions }\end{array}$ & $\begin{array}{l}\text { Histological classification (WHO } \\
\text { criteria) }\end{array}$ & $\begin{array}{l}\text { Lymph node } \\
\text { invasion }^{\mathrm{a}}\end{array}$ & $\begin{array}{l}\text { TWIST1 status } \\
(\text { mean } \pm \mathrm{SD})^{\mathrm{b}}\end{array}$ & $\begin{array}{l}\text { DNA sequence } \\
\text { analysed }\end{array}$ & $\begin{array}{l}\text { Clinical } \\
\text { outcome }^{\mathrm{c}}\end{array}$ \\
\hline 1 & Single & Fibroadenomatous change & Absent & ( ) $2.67 \pm 0.58$ & Yes, no variations & DC \\
\hline 2 & Single & Fibroadenomatous change & Absent & ( ) $4.00 \pm 0.00$ & No & NED \\
\hline 3 & Single & Lobular hyperplasia & Absent & ( ) $1.25 \pm 0.44$ & No & NED \\
\hline 4 & Single & Low-cellularity fibroadenoma & Absent & ( ) $4.00 \pm 0.00$ & Yes, no variations & NED \\
\hline 5 & Multiple & Papillary carcinoma & Absent (N) & ( ) $0.38 \pm 0.00$ & No & NED \\
\hline 6 & Multiple & Tubular carcinoma & Absent $(\mathrm{N})$ & ( ) $0.74 \pm 0.00$ & Yes, no variations & NED \\
\hline 7 & Multiple & Tubulopapillary carcinoma & Absent (V) & ( ) $0.53 \pm 0.04$ & g. $460 \mathrm{C}>\mathrm{T} ; \mathrm{g} .535 \mathrm{delG}$ & DOC \\
\hline 8 & Multiple & Tubulopapillary carcinoma & Present (V) & ( ) $0.32 \pm 0.02$ & No & DOC \\
\hline 9 & Multiple & Tubulopapillary carcinoma & Absent (V) & ( ) $0.39 \pm 0.00$ & No & DOD \\
\hline 10 & Single & Tubulopapillary/solid carcinoma & Present (V) & ( ) $0.20 \pm 0.00$ & Yes, no variations & DOD \\
\hline 11 & Multiple & Cribriform/solid carcinoma & Present (V) & ( ) $0.36 \pm 0.00$ & No & DOD \\
\hline 12 & Multiple & Cribriform carcinoma & Present (V) & ( ) $1.26 \pm 0.09$ & No & DOD \\
\hline 13 & Multiple & Tubulopapillary carcinoma & Present (V) & ( ) $0.35 \pm 0.02$ & No & DOD \\
\hline 14 & Multiple & Tubulopapillary carcinoma & Present (V) & ( ) $0.29 \pm 0.02$ & No & DOD \\
\hline 15 & Multiple & Tubulopapillary carcinoma & Present (V) & ( ) $0.36 \pm 0.01$ & No & DOD \\
\hline 16 & Multiple & Tubulopapillary carcinoma & Present (V) & ( ) $0.18 \pm 0.02$ & No & DOD \\
\hline 17 & Multiple & Tubulopapillary carcinoma & Present (V) & ( ) $0.21 \pm 0.06$ & No & NED \\
\hline 18 & Multiple & Tubulopapillary carcinoma & Present (V) & ( ) $1.21 \pm 0.14$ & No & NED \\
\hline
\end{tabular}

a V, vascular invasion; $\mathrm{N}$, no vascular invasion.

b SD, standard deviation; ( ), down-regulated; concentration ratio 100 when compared to the control group (5.36 \pm 1.83 ).

c DOD, dead of disease; NED, no evidence of disease ( for more than 2 years); DOC, death from other causes; DC, this queen (queen 1) subsequently developed two carcinomas (samples 15 and 16) 